\title{
Evaluation of angler reporting accuracy in an off-site survey to estimate statewide steelhead harvest
}

\author{
J. L. MCCORMICK \\ Oregon Department of Fish and Wildlife, Salem, OR, USA \\ D. WHITNEY \\ Idaho Department of Fish and Game, Lewiston, ID, USA \\ D. J. SCHILL \\ Idaho Department of Fish and Game, Nampa, ID, USA
}

M. C. QUIST

U.S. Geological Survey, Idaho Cooperative Fish and Wildlife Research Unit, Department of Fish and Wildlife Sciences, University of Idaho, Moscow, ID, USA

\begin{abstract}
Accuracy of angler-reported data on steelhead, Oncorhynchus mykiss (Walbaum), harvest in Idaho, USA, was quantified by comparing data recorded on angler harvest permits to the numbers that the same group of anglers reported in an off-site survey. Anglers could respond to the off-site survey using mail or Internet; if they did not respond using these methods, they were called on the telephone. A majority of anglers responded through the mail, and the probability of responding by Internet decreased with increasing age of the respondent. The actual number of steelhead harvested did not appear to influence the response type. Anglers in the autumn 2012 survey overreported harvest by $24 \%$, whereas anglers in the spring 2013 survey under-reported steelhead harvest by $16 \%$. The direction of reporting bias may have been a function of actual harvest, where anglers harvested on average 2.6 times more fish during the spring fishery than the autumn. Reporting bias that is a function of actual harvest can have substantial management and conservation implications because the fishery will be perceived to be performing better at lower harvest rates and worse when harvest rates are higher. Thus, these findings warrant consideration when designing surveys and evaluating management actions.
\end{abstract}

K E Y W O R D S: $\quad$ angler survey, harvest, human dimensions, off-site survey, Oncorhynchus mykiss, self-reporting bias.

\section{Introduction}

Off-site angler surveys such as mail, telephone and Internet surveys can provide a relatively inexpensive alternative for collecting fisheries data compared to on-site surveys such as roving and access creel surveys (Brown 1991; Weithman 1991; Pollock et al. 1994; Connelly et al. 2000). Although off-site surveys are commonly conducted to gain knowledge on angler opinion and economic contributions from fishing activity, they can also be used to estimate angling effort and catch (Weithman 1991; Weithman \& Haverland 1991; Pollock et al. 1994). Both on- and off-site techniques generally rely on some form of angler self-reported data to generate estimates of effort and catch that can be sensitive to angler self-reporting bias (i.e. inaccurate data reported by 
anglers; Robson 1961; Hayne 1991; Pollock et al. 1994). Both survey types may be susceptible to multiple forms of response bias such as prestige bias, deliberate misreporting bias, recall bias and non-response bias (Pollock et al. 1994). Although some self-reporting bias has been documented (Edwards 1971; Sullivan 2003; McCormick et al. 2013), on-site surveys are generally considered to be less sensitive to self-reporting bias than off-site surveys because catch can be inspected and anglers are interviewed during or shortly after their fishing trip (Carline 1972; Essig \& Holliday 1991; Pollock et al. 1994; Roach et al. 1999). Because of the close temporal proximity of fishing activity and interviews, on-site interviews of anglers are unlikely to suffer from inaccurate recall that often occurs in off-site surveys (Pollock et al. 1994; Connelly et al. 2000; Connelly \& Brown 2011). However, Pollock et al. (1994) suggested that recall bias may be low in off-site surveys if species are rare and catch is memorable. With the exception of Chinook salmon, Oncorhynchus tshawytscha (Walbaum), coho salmon, O. kisutch (Walbaum), and white sturgeon, Acipenser transmontanus (Richardson), catch rates of steelhead, O. mykiss (Walbaum), in Idaho, USA, are generally lower and size is generally larger than other popular sport fish in the region (Idaho Department of Fish and Game [IDFG], unpublished data). These characteristics likely place them in the 'memorable' or 'rare' category described by Pollock et al. (1994).

Wild summer steelhead in the Snake River distinct population segment in Idaho are currently listed as threatened under the Endangered Species Act (ESA; Nehlsen et al. 1991; Meyers et al. 1998). As a result of declining steelhead populations in the Snake River basin since the early 1900s, hatchery production has been adopted to supplement wild stocks and provide sport, commercial and ceremonial tribal fisheries. Harvest in sport fisheries is currently limited to hatchery-origin steelhead with a clipped adipose fin that are not listed under the ESA. All non-adipose clipped steelhead must be immediately released if caught in sport fisheries that target hatchery steelhead. To evaluate progress towards supplementation management objectives, season-long statewide steelhead harvest estimates are required (McArthur 1992).

Steelhead fisheries in Idaho occur over hundreds of kilometres of rivers and streams throughout most of the year that makes on-site surveys cost-prohibitive. As a result, IDFG estimates total steelhead harvest using an off-site statewide angler survey that includes mail, telephone and Internet response options (hereafter referred to as the 'off-site survey'; Pollard 1982; McArthur 1992). The spring steelhead sport-fishing season typically extends from January through May, and the autumn season typically extends from August through
December. The off-site survey is conducted in May to estimate harvest in the spring fishery and again in January of the following year to estimate harvest in the previous autumn. Due to the timing of off-site surveys, the potential for significant recall bias is high (Essig \& Holliday 1991; Pollock et al. 1994; Connelly et al. 2000). Pollock et al. (1994) suggested that recall bias can occur after 2 months and for some biological metrics that require high accuracy, surveys should not rely on more than a 1-week recall. The current design of the IDFG off-site survey interviews anglers up to 6 months after they fished.

Although some form of off-site survey to estimate steelhead harvest in Idaho has been conducted since 1954, including early attempts to address reporting bias (Simpson \& Bjornn 1965), bias associated with the current version of the off-site survey has never been intensively evaluated. Thus, the objective of this research was to assess bias associated with the current statewide offsite survey and examine factors that may be influencing bias.

\section{Methods}

The approach to quantify reporting bias in this study was to record data from a sample of harvest permits from anglers in the field (i.e. on-site survey), subsequently contact them in an off-site survey and then compare their recorded harvest permit data to their selfreported data from the off-site survey. This process was repeated for two fishing seasons (i.e. autumn of 2012 and spring of 2013), and independent samples of anglers were taken each season. Anglers were required to purchase a steelhead harvest permit to fish for steelhead in Idaho; when they harvested a steelhead, to immediately remove a numbered notch from their permit and record the river location code, month and day. Every angler who purchased a steelhead harvest permit was assigned a unique permit identification number, and their name, address and phone number were recorded in a database and linked to the permit number. Harvest permits are issued on an annual basis, so anglers who fished in the spring were required to retain their permits for the autumn fishery. However, after the autumn season, although anglers were encouraged to retain their permits, they were no longer valid for fishing (i.e. the fishing season in that calendar year is over), and anglers were required to purchase a new permit for the following calendar year. It was expected that recall would be more accurate in the spring off-site survey because most anglers would retain their permit and could use it as a reference during the survey, whereas permit retention was not as likely during the autumn survey. 
Anglers are required by law to record harvested steelhead on their permits. Given the uncertainty of being checked by law enforcement personnel while angling and the lack of disincentives to recording harvested fish (including relatively liberal daily and season bag limits of hatchery steelhead), it was assumed that anglers accurately recorded harvest of steelhead on their permits. If this assumption was violated, this study can still be interpreted as a catch comparison between harvest permits and an off-site survey rather than a true estimate of bias in an off-site survey.

\section{On-site survey}

Creel clerks collected information from harvest permits while conducting creel surveys where the primary objective was to obtain steelhead catch rate data (Hansen 2011). Harvest permit data were recorded from anglers on the Clearwater, North Fork Clearwater, South Fork Clearwater, Salmon and Little Salmon rivers. On-site survey days were selected using a random-systematic survey design on the Clearwater, North Fork Clearwater and South Fork Clearwater rivers. A non-random sampling design was used on the Salmon and Little Salmon rivers where survey days were chosen to maximise angler interviews. Harvest permit data were recorded from both completed trip interviews at access sites and during roving surveys, which were primarily incomplete trips. Information recorded from harvest permits included the unique permit identification number, date and river location of harvested fish, the total number of fish recorded on the permit and comments from the clerk concerning the permit. Comments included illegible records, incorrect river location records and observed harvest without accompanying records. To avoid influencing angler response in future on-site or off-site surveys, recording errors were not brought to the angler's attention. Anglers who failed to record harvested fish that were observed the day of the survey were not included in the analysis because of known inaccuracies on their harvest permits. Anglers who inquired about the reason for recording information from harvest permits were told by creel clerks that biologists were using the information to estimate harvest.

\section{Off-site survey}

Contact information for anglers encountered during the on-site survey was obtained through the IDFG licence database that requires anglers to enter their address and telephone number when they purchase a licence. Every angler encountered in the field was mailed a questionnaire about their fishing experience to which they could respond via mail or the Internet. Questionnaires were mailed in late January for the autumn survey and late May for the spring survey. If an angler did not respond within a 2-week period, they were surveyed by telephone. In the off-site survey, anglers were asked to report the number of days fished, the number of hatchery steelhead harvested by river location code and month and the number of hatchery and wild steelhead released by river location.

\section{Data analysis}

Although anglers were asked to report their information by river location and month, data were summarised by season and across all management sections in Idaho due to sample size constraints. Because anglers may have harvested fish after they were encountered in the on-site survey, only steelhead harvested in months previous to the month they were encountered were used for the comparison between observed and reported data. For example, if an angler was encountered in April in the on-site survey, only fish that were recorded on their harvest permit and reported in the off-site survey from January through March were used for the comparison.

The probability of an angler using the three response types (i.e. mail, Internet, telephone) was modelled using multinomial logistic regression models (Fox 2008). Multinomial logistic regression is similar to logistic regression but allows probabilities to be estimated for more than two categorical responses. Nine a priori candidate models were created using various combinations of covariates such as age and sex of the respondent, whether the respondent was a resident, season, month of on-site encounter and observed harvest. Candidate models were evaluated using model selection methods described by Burnham and Anderson (2002). Coefficients in multinomial logistic regression models are expressed as natural log odds ratios of a given response type relative to a reference category. All coefficients were exponentiated in the results section, so the odds ratios could be interpreted on the real number scale.

Linear regression models were created to evaluate the relationship between reporting bias (i.e. reported harvest off-site minus observed harvest on harvest cards) in steelhead harvest from anglers and covariates that were collected during the off-site or on-site surveys (i.e. age and sex of respondent, whether the respondent was a resident, response type, season, month encountered in field), as well as the observed harvest. Eighteen a priori candidate models were evaluated using model selection methods described by Burnham and Anderson (2002). Akaike weights $\left(w_{i}\right)$ were used to assess the relative support of each candidate model. 
Although the reported number of hatchery and wild steelhead released and the number of days fished could not be evaluated for accuracy, they are still of interest to managers. As a result, the ratio of hatchery to wild fish caught and days fished were compared for anglers that had $100 \%$ congruence of reported harvest in the on-site and off-site surveys, anglers that overreported harvest and anglers that underreported harvest. Both metrics for each category of angler were examined by season. These analyses were conducted under the assumption that anglers who accurately reported harvest were more likely to accurately report hatchery and wild fish catches, as well as days fished. All analyses were conducted using the $\mathrm{R}$ statistical computing language ( $\mathrm{R}$ Development Core Team 2009).

\section{Results}

Six hundred and forty-one anglers were contacted in the autumn 2012 on-site survey, and 751 anglers were contacted in the spring 2013 survey. However, only 368 anglers subsequently responded in the off-site survey in the autumn, and 332 anglers responded in the spring. Anglers reported fishing an average of $8.8 \pm 12.7$ days (mean $\pm \mathrm{SD}$ ) during the autumn fishery and $9.2 \pm 13.2$ days during the spring fishery. Seven percent of anglers who were interviewed in the on-site survey during the autumn fishery and $5 \%$ in the spring fishery reported in the off-site survey that they did not fish for steelhead. Two of the 24 autumn anglers who reported not fishing for steelhead had recorded at least one steelhead on their harvest permits. Six of the 15 spring anglers who reported that they did not fish for steelhead had recorded at least one harvested steelhead on their harvest permit.

\section{Response rates}

Of the 700 total off-site survey respondents, $4 \%$ responded by Internet, $65 \%$ by mail and $31 \%$ were contacted by telephone. Only 10 of the 31 Internet respondents reported their age, but all anglers using other response types reported their age. Anglers who did not report their age were not included in the multinomial logistic regression analysis. The model to predict response probability that included a covariate for age was the best supported of the a priori models and accounted for an estimated $44 \%$ of the $w_{i}$ (Table 1). Results of the age-only model indicated that the odds of an angler responding by telephone or Internet compared to mail decreased by 1.04 times with a one-unit (i.e. year) increase in age, and the odds of an angler responding by Internet compared to telephone decreased by 1.01
Table 1. Comparison of multinomial logistic regression models that estimated reporting probabilities of anglers in an off-site survey to estimate steelhead harvest in Idaho by response type (i.e. telephone, Internet, mail)

\begin{tabular}{lcccr}
\hline Model & K & AIC & $\Delta$ AIC & $w_{i}$ \\
\hline Age & 4 & 910.10 & 0 & 0.44 \\
Sex + Age + Resident & 8 & 910.73 & 0.63 & 0.32 \\
Sex + Age + Resident & 14 & 912.73 & 2.63 & 0.12 \\
$\quad+$ Observed harvest & & & & \\
$\quad+$ Month + Season & & & & \\
Sex + Age & 6 & 912.75 & 2.65 & 0.12 \\
Season & 4 & 946.16 & 36.06 & $<0.01$ \\
Resident & 4 & 948.90 & 38.8 & $<0.01$ \\
Intercept only & 2 & 949.85 & 39.75 & $<0.01$ \\
Observed harvest & 4 & 951.84 & 41.74 & $<0.01$ \\
Sex & 4 & 952.57 & 42.47 & $<0.01$ \\
\hline
\end{tabular}

Number of parameters $(K)$, Akaike's information criteria (AIC), change in AIC value ( $\triangle \mathrm{AIC})$ and AIC weights $\left(w_{i}\right)$ were used to select the better supported models from a set of a priori candidate models. Variables considered in the models included age and sex of the respondent, whether the respondent was a resident of the state of Idaho (i.e. resident), month and season (i.e. autumn or spring) of encounter in the onsite survey and observed harvest in the on-site survey.

times with a one-unit increase in age (Table 2). Although the age-only model was considered the most parsimonious, the model that incorporated covariates for sex, age and residency accounted for an estimated $32 \%$ of the $w_{i}$ (Table 1).

\section{Reporting bias}

During the autumn fishery, the 368 anglers who responded to the off-site survey recorded 195 harvested steelhead ( 0.5 fish per angler) on their harvest permits, but reported harvesting 242 steelhead $(0.7$ fish per

Table 2. Parameter estimates, standard errors (SE) and $95 \%$ confidence interval for the best supported multinomial logistic regression model that estimated reporting probabilities of anglers in an off-site survey to estimate steelhead harvest in Idaho by response type (i.e. telephone, Internet, mail)

\begin{tabular}{lllll}
\hline & & & \multicolumn{2}{l}{ Confidence interval } \\
\cline { 4 - 5 } Variable & Estimate & SE & Lower & Upper \\
\hline Telephone & & & & \\
Intercept & 2.630 & 1.319 & 1.528 & 4.526 \\
Age & 0.964 & 1.006 & 0.953 & 0.976 \\
Internet & & & & \\
Intercept & 0.136 & 2.625 & 0.020 & 0.899 \\
Age & 0.962 & 1.021 & 0.923 & 1.002 \\
\hline
\end{tabular}

Coefficients are interpreted as odds ratios relative to reporting probability by mail (i.e. mail was the reference category). 
angler), an overestimate of 47 steelhead (24\%). Despite the overestimate, $20 \%$ of the anglers recorded at least one harvested steelhead on their harvest permits, but only $17 \%$ of anglers reported that they harvested at least one steelhead in the off-site survey. During the autumn fishery, $83 \%$ of the 368 anglers surveyed reported their harvest with $100 \%$ accuracy (Fig. 1).

Of the 305 anglers who accurately reported their harvest, $91 \%$ did not harvest a steelhead. Thirty-five percent of the 75 anglers in the autumn on-site survey who were successful in harvesting a steelhead reported their harvest accurately in the off-site survey. Thirty-nine percent of successful anglers underreported harvest, and $27 \%$ overreported harvest.

During the spring fishery, the 332 anglers who responded to the off-site survey recorded 420 harvested steelhead on their harvest permits (1.3 fish per angler), but reported harvesting 351 steelhead (1.1 per angler), an overestimate of 69 steelhead (16\%). Thirty-five percent of anglers recorded at least one steelhead on their harvest permits, but only $26 \%$ of anglers reported in the off-site survey that they had harvested at least one steelhead.

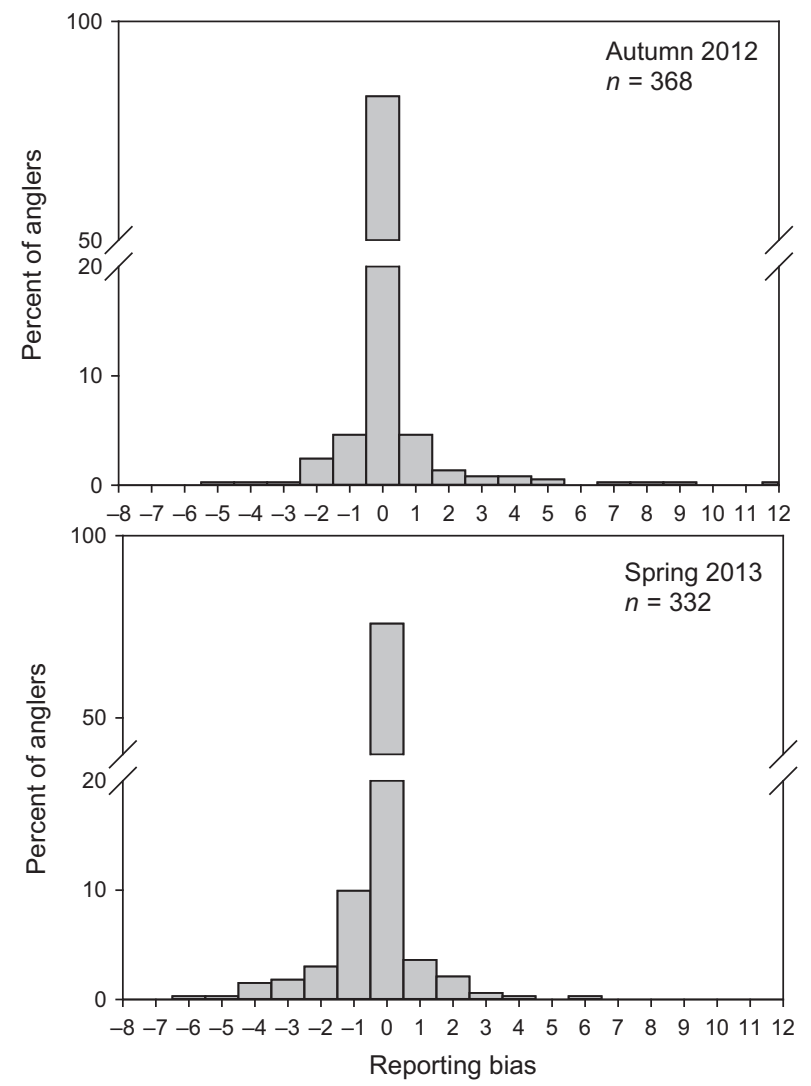

Figure 1. Reporting bias (i.e. reported minus observed) of harvested steelhead in Idaho sport fisheries during the autumn 2012 and spring 2013 seasons.
During the spring survey, $76 \%$ of anglers reported their harvest with $100 \%$ accuracy (Fig. 1). Of the 252 anglers who accurately reported harvest, $83 \%$ did not have a harvested steelhead recorded on their harvest permits at the time of the on-site survey. Four percent of anglers who did not record a steelhead on their harvest permits reported in the off-site survey that they harvested at least one steelhead.

During the spring season, $31 \%$ of the 116 anglers who were successful in harvesting at least one steelhead reported that they did not harvest a steelhead in the offsite survey. Of the 116 anglers who were successful in harvesting a steelhead, $38 \%$ accurately reported harvest, $49 \%$ underreported harvest, and $13 \%$ overreported harvest.

The best supported linear regression model for reporting bias included covariates for season and observed harvest as well as the interaction term of observed harvest and season (Tables 3 and 4). This model, however, accounted for little of the variation in reporting bias and accounted for $97 \%$ of the $w_{i}$. The second best supported model, and the only other candidate model that accounted for greater than $0.01 \%$ of the $w_{i}$, included the terms in the top model and all other covariates considered.

\section{Evaluation of wild steelhead catch and angling effort}

The 305 anglers who accurately reported the number of fish harvested during the autumn fishery reported catching 1.14 (95\% CI: 0.95-1.40) wild fish for every hatchery fish caught in the off-site survey. Anglers who overreported harvest during the autumn fishery reported catching $0.63(0.41-0.87)$ wild steelhead per hatchery steelhead, and anglers who underreported harvest reported catching $1.04(0.43-2.81)$ wild steelhead per hatchery steelhead.

The 252 anglers who accurately reported the number of fish harvested during the spring fishery reported in the off-site survey that they caught 1.71 (95\% CI: $1.31-$ 2.29) wild fish for every hatchery fish caught. Anglers who overreported harvest during the spring fishery reported catching $1.11(0.63-2.23)$ wild steelhead per hatchery steelhead, and anglers who underreported harvest reported catching $0.99(0.59-1.72)$ wild steelhead per hatchery steelhead.

Anglers who accurately reported the number of fish harvested during the autumn fishery reported fishing for an average of 9.5 ( $\mathrm{SD} \pm 12.9)$ days. Anglers who overreported harvest during the autumn fishery reported in the off-site survey that they fished for an average of $14.1 \pm 13.9$ days, and anglers who underreported harvest reported fishing for $18.6 \pm 23.4$ days. Anglers who 
Table 3. Linear regression models that estimated reporting bias (i.e. reported harvest minus observed harvest) in an off-site survey to estimate steelhead harvest in Idaho sport fisheries

\begin{tabular}{|c|c|c|c|c|c|}
\hline Model & $K$ & AIC & $\Delta \mathrm{AIC}$ & $w_{i}$ & $R^{2}$ \\
\hline $\mathrm{OH}+$ Season $+(\mathrm{OH} \times$ Season $)$ & 5 & 2198.7 & 0.0 & 0.97 & 0.06 \\
\hline $\mathrm{OH}+\mathrm{Sex}+$ Age + Month + Season $+\mathrm{RT}+$ Resident $+(\mathrm{OH} \times$ Season $)$ & 11 & 2205.9 & 7.2 & 0.03 & 0.07 \\
\hline $\mathrm{OH}+\mathrm{Sex}+\mathrm{Age}+$ Month + Season $+\mathrm{RT}+$ Resident & 10 & 2219.0 & 20.2 & $<0.01$ & 0.05 \\
\hline Month & 3 & 2221.1 & 22.4 & $<0.01$ & 0.02 \\
\hline $\mathrm{OH}$ & 3 & 2223.1 & 24.4 & $<0.01$ & 0.02 \\
\hline Season & 3 & 2223.3 & 24.6 & $<0.01$ & 0.02 \\
\hline Sex + Age + Month + Season + Resident & 7 & 2227.0 & 28.3 & $<0.01$ & 0.02 \\
\hline Age + Month + Season + RT + Resident & 8 & 2227.2 & 28.4 & $<0.01$ & 0.03 \\
\hline Sex + Month + Season + RT + Resident & 8 & 2227.3 & 28.5 & $<0.01$ & 0.03 \\
\hline Sex + Age + Month + Season + RT & 8 & 2227.3 & 28.6 & $<0.01$ & 0.03 \\
\hline Sex + Age + Month + RT + Resident & 8 & 2228.9 & 30.2 & $<0.01$ & 0.03 \\
\hline Sex + Age + Season + RT + Resident & 8 & 2231.0 & 32.3 & $<0.01$ & 0.02 \\
\hline Intercept only & 2 & 2234.2 & 35.5 & $<0.01$ & - \\
\hline Age & 3 & 2236.0 & 37.3 & $<0.01$ & 0.01 \\
\hline Resident & 3 & 2236.2 & 37.5 & $<0.01$ & 0.01 \\
\hline Sex & 3 & 2236.2 & 37.5 & $<0.01$ & 0.01 \\
\hline RT & 4 & 2236.9 & 38.2 & $<0.01$ & 0.01 \\
\hline Sex + Age & 4 & 2238.0 & 39.3 & $<0.01$ & 0.01 \\
\hline
\end{tabular}

Akaike's information criteria (AIC), number of parameters $(K)$, change in AIC value ( $\triangle \mathrm{AIC}$ ), and AIC weights $\left(w_{i}\right)$ and coefficient of determination $\left(R^{2}\right)$ were used to select the best supported models from a set of a priori candidate models. Variables considered in the models included age and sex of the respondent, whether the respondent was a resident of the state of Idaho (i.e. resident), month and season of encounter in the on-site survey, type of response in the off-site survey (RT; i.e. mail, Internet, telephone) and observed number of fish harvested (OH) in the on-site survey.

Table 4. Parameter estimates, standard errors (SEs) and 95\% confidence interval for the top linear regression model that estimated reporting bias of harvested steelhead in Idaho reported by anglers in an offsite survey

\begin{tabular}{lrlll}
\hline & & & \multicolumn{2}{c}{ Confidence interval } \\
\cline { 3 - 5 } Variable & Estimate & SE & Lower & Upper \\
\hline Intercept & 0.0833 & 0.0694 & -0.433 & 0.600 \\
Observed harvest & 0.0923 & 0.0423 & -0.310 & 0.495 \\
Season (spring) & -0.1382 & 0.1012 & -0.762 & 0.485 \\
Observed harvest & -0.2137 & 0.0489 & -0.647 & 0.220 \\
$\quad \times$ season (spring) & & & & \\
\hline
\end{tabular}

accurately reported the number of fish harvested during the spring fishery reported fishing for an average of $8.0 \pm$ 12.9 days. Anglers who overreported harvest during the spring fishery reported fishing for an average of $18.6 \pm 18.4$ days, and anglers who underreported harvest reported fishing for $10.8 \pm 10.8$ days.

\section{Discussion}

Although the majority of anglers accurately reported harvest, results of this study suggest that off-site surveys provided erroneous estimates of steelhead harvest. During the late 1950s and early 1960s, Simpson and Bjornn (1965) found that estimates of statewide steelhead har- vest in Idaho were positively biased when voluntary harvest permit surveys were used. The authors suggested that this was likely a result of non-response bias where anglers who returned the postal survey or harvest permits were more successful than the general angling public. Similar results have been found in other studies (Carline 1972; Roach et al. 1999; Connelly et al. 2000). Simpson and Bjornn (1965) found that when a random sample of harvest permit holders was conducted (similar to the current survey design), estimates of steelhead harvest were similar to on-site creel surveys that did not suffer from non-response bias. This result was the impetus for the current survey design used to estimate steelhead harvest in Idaho. However, in addition to non-response bias, the authors suggested that some of their estimates were potentially biased due to inaccurate data provided by anglers in the postal survey. This bias, resulting from recall bias, prestige bias or deliberate misreporting bias is likely what caused inaccurate results in the current study (i.e. the difference between what was observed in the on-site and off-site surveys) but was probably not a function of the response method used in the off-site survey (Pollock et al. 1994).

Although the exact reason for bias in the current study is unknown, it is likely a combination of multiple sources. Due to the relatively low catch of steelhead, it is unlikely that anglers underreported harvest because of poor recall when they only harvested one or few fish. 
However, this may not have been the case for anglers who caught many fish. One possible explanation for underreporting of harvested steelhead is deliberate misreporting bias (Pollock et al. 1994). McCormick et al. (2013) found that, although a majority of anglers were accurate in reporting catch, a minority of anglers were deliberately misreporting harvest and catch of both hatchery and wild Chinook salmon in Idaho sport fisheries, perhaps in an attempt to influence season length. Although steelhead fisheries are not managed as intensively as Chinook salmon fisheries, naturally produced steelhead in Idaho are ESA-listed, which may have influenced the reporting accuracy of those anglers who underreported harvest.

Although it is unknown why anglers underreported harvest in the spring and overreported in the autumn, the direction of the bias may be related to the actual harvest. On average, anglers were 2.6 times more likely to harvest a steelhead in the spring compared to the autumn. Sullivan (2003) found similar results in that exaggeration of catch of walleye, Sander vitreus (Mitchill), increased exponentially with decreasing catch rates in sport fisheries in Alberta, Canada, and that exaggeration primarily occurred at low catch rates. Contrary to Sullivan (2003), the current results suggest that individual anglers were inaccurately reporting (both over and underreporting) at both high and low catch rates in the spring fishery; however, anglers had a greater tendency to overreport harvest when catch rates were low (i.e. autumn fishery).

The accuracy of self-reported harvest of steelhead did not appear to be affected by the method that anglers used to respond to the survey (i.e. mail, phone or Internet). Previous research has shown that voluntary angler surveys (i.e. mail surveys) are susceptible to non-response bias and that successful anglers are more likely to respond than less successful anglers (Carline 1972; Connelly \& Brown 1995; Roach et al. 1999; Connelly et al. 2000). Results of the current study are contrary to these studies in that more successful anglers (i.e. anglers with higher observed harvest) were not more likely to voluntarily respond to the survey (i.e. choosing to respond by mail or Internet instead of by telephone). However, the time between the initial mail survey and the follow-up phone survey was relatively short (i.e. 2 weeks). A longer duration between the two surveys may have given different results. Although sample size was small, younger anglers showed a slight tendency to respond using the Internet at higher rates than older anglers who tended to respond by mail or telephone. With access to Internet becoming ubiquitous and development of mobile technology increasing, it is likely that future off-site fisheries' surveys that take advantage of this technology will increase. Managers and researchers administering such surveys should be aware that younger anglers may be more likely to respond using these methods.

Although off-site surveys are likely more susceptible to reporting bias, they are also generally much less expensive than on-site surveys for the same temporal and spatial coverage (Weithman 1991). Some researchers have suggested using a correction factor or assuming reporting bias is constant and managing based on trends (Connelly \& Brown 1995; Roach et al. 1999; Connelly et al. 2000). The linear regression models used in this study accounted for only a small portion of the variation in reporting bias, suggesting that adjusting off-site estimates based on one or more factors may not be useful. Additionally, differences in reporting bias by season in the current study may preclude the use of a single correction factor to account for reporting bias. Connelly and Brown (2011) also found differences in reporting bias of angling effort at different temporal scales in fisheries in New York. Sullivan (2003) suggested that if anglers are more likely to exaggerate at lower catch rates, which may have been the reason for disparity of reporting bias among seasons in the current study, hyperstability of the fishery can occur, where the fishery is believed to be performing better at lower abundances than it actually is and worse than it actually is at higher abundances. From a conservation perspective, catchdependent reporting bias can have serious implications when managing fisheries based on trends because the slope of negative trends will typically be underestimated and can lead to incorrect conclusions about the effect of management or conservation actions or the trajectory of the population.

The estimated reporting bias in the present study may be conservative because Idaho steelhead anglers are not typically asked to show their permit to and have data recorded by IDFG survey personnel in the field. This could have led to more accurate reporting in the off-site survey than when surveying the general population of anglers. Regardless, bias was still substantial and, given the importance of steelhead fisheries, should be accounted for by managers when designing surveys and evaluating management actions. However, reporting bias surveys were only conducted for two seasons and more research is needed to understand fully the relationship between angler catch rates and reporting bias. It is generally accepted that on-site surveys have less potential for bias (Carline 1972; Essig \& Holliday 1991; Roach et al. 1999), but, because of the cost, on-site surveys may not be realistic to implement at large scales. Results of this study suggest that bias may be as high as $24 \%$ in one fishing season, and it is unlikely that bias can be corrected as evidenced by the temporal patterns of bias observed. Ultimately, managers will need to decide the 
level of bias they are willing to accept as a function of cost when determining which survey type to implement. If the level of bias observed in this study is unacceptable, on-site surveys may be the only option to reduce bias. If off-site surveys are the only option due to expense, managers should at least acknowledge potential reporting bias when making management decisions or make attempts to educate the angling public on the importance of accurately reporting harvest.

\section{Acknowledgments}

We thank T. McArthur for administering and summarising the data in the off-site survey and IDFG creel clerks for conducting the on-site survey. We thank M. Gauvin and B. Wright for providing helpful comments on earlier versions of this manuscript. Funding for this project was provided by the Idaho Department of Fish and Game through the Lower Snake River Compensation Plan. The Idaho Cooperative Fish and Wildlife Research Unit is jointly sponsored by the University of Idaho, U.S. Geological Survey, Idaho Department of Fish and Game, and Wildlife Management Institute. The use of trade, firm or product names is for descriptive purposes only and does not imply endorsement by the U.S. government.

\section{References}

Brown T.L. (1991) Use and abuse of mail surveys. In: D. Guthrie, J.M. Hoenig, M. Holliday, C.M. Jones, M.J. Mills, S.A. Moberly, K.H. Pollock \& D.R. Talhelm (eds) Creel and Angler Surveys in Fisheries Management. Bethesda, MD: American Fisheries Society, Symposium 12, pp. 255-261.

Burnham K.P. \& Anderson D.R. (2002) Model Selection and Multimodel Inference, 2nd edn. New York: Springer-Verlag, $488 \mathrm{pp}$.

Carline R.F. (1972) Biased harvest estimates from a postal survey of a sport fishery. Transactions of the American Fisheries Society 101, 262-266.

Connelly N.A. \& Brown T.L. (1995) Use of angler diaries to examine biases associated with 12-month recall on mail questionnaires. Transactions of the American Fisheries Society 124, 413-422.

Connelly N.A. \& Brown T.L. (2011) Effect of recall period on annual freshwater fishing effort estimates in New York. Fisheries Management and Ecology 18, 83-87.

Connelly N.A., Brown T.L. \& Knuth B.A. (2000) Assessing the relative importance of recall bias and nonresponse bias and adjusting for those biases in statewide angler surveys. Human Dimensions of Wildlife 5, 19-29.

Edwards G.B. (1971) Actual versus reported fishing times as a factor in creel census data. The Progressive Fish-Culturist 33, $54-54$.
Essig R.J. \& Holliday M.C. (1991) Development of a recreational fishing survey: the marine recreational fishery statistics survey case study In: D. Guthrie, J.M. Hoenig, M. Holliday, C.M. Jones, M.J. Mills, S.A. Moberly, K.H. Pollock \& D.R. Talhelm (eds) Creel and Angler Surveys in Fisheries Management. Bethesda, MD: American Fisheries Society, Symposium 12, pp. 245-254.

Fox J. (2008) Applied Regression Analysis and Generalized Linear Models, 2nd edn. Thousand Oaks, CA: Sage Publications, 665 pp.

Hansen J. (2011) Evaluation of Idaho Steelhead Harvest for Lower Snake River Compensation Plan Hatchery Programs. Boise, ID: Idaho Department of Fish and Game, 128 pp.

Hayne D.W. (1991) The access point creel survey: procedures and comparison with the roving-clerk creel survey. In: D. Guthrie, J.M. Hoenig, M. Holliday, C.M. Jones, M.J. Mills, S.A. Moberly, K.H. Pollock \& D.R. Talhelm (eds) Creel and Angler Surveys in Fisheries Management. Bethesda, MD: American Fisheries Society, Symposium 12, pp. 123-138.

McArthur T.J. (1992) Technical Assistance and Modeling 19901991 Steelhead Season Harvest and Effort (Telephone Survey). Boise, ID: Idaho Department of Fish and Game, 45 pp.

McCormick J.L., Quist M.C. \& Schill D.J. (2013) Self-reporting bias in Chinook salmon sport fisheries in Idaho: implications for roving creel surveys. North American Journal of Fisheries Management 33, 723-731.

Meyers J.M., Kope R.G., Bryant G.J., Teel D., Leirheimer L.J., Wainwrith T.C. et al. (1998) Status Review of Chinook Salmon from Washington, Idaho, Oregon and California. Washington, D.C.: U.S. Department of Commerce, National Oceanic and Atmospheric Administration, National Marine Fisheries Service Report 35, 478 pp.

Nehlsen W., Williams J.E. \& Lichatowich J.A. (1991) Pacific salmon at the crossroads: stocks at risk from California, Oregon, Idaho, and Washington. Fisheries 16, 4-21.

Pollard H.A. (1982) Study I: Estimates of the 1982 Harvest of Salmon and Steelhead (Survey). Subproject II. Salmon and Steelhead Investigations Project F-73-R-5. Boise, ID: Idaho Department of Fish and Game, 25 pp.

Pollock K.H., Jones C.M. \& Brown T.L. (1994) Angler Survey Methods and Their Applications in Fisheries Management. Bethesda, MD: American Fisheries Society Special Publication 25, 370 pp.

R Development Core Team (2009) R: A Language and Environment for Statistical Computing. Vienna: R Foundation for Statistical Computing.

Roach B., Trial J. \& Boyle K. (1999) Comparing 1994 angler catch and harvest rates from on-site and mail surveys on selected Maine lakes. North American Journal of Fisheries Management 19, 203-208.

Robson D.S. (1961) On statistical theory of a roving creel census of fishermen. Biometrics 17, 415-437.

Simpson J.C. \& Bjornn T.C. (1965) Methods used to estimate salmon and steelhead harvests in Idaho. Proceedings of the 
Annual Conference of the Western Association of State Game and Fish Commissioners 89, 1-21.

Sullivan M.G. (2003) Exaggeration of walleye catches by Alberta anglers. North American Journal of Fisheries Management 23, 573-580.

Weithman A.S. (1991) Telephone survey preferred in collecting angler data statewide. In: D. Guthrie, J.M. Hoenig, M. Holliday, C.M. Jones, M.J. Mills, S.A. Moberly, K.H. Pollock \& D.R. Talhelm (eds) Creel and Angler Surveys in Fisheries
Management. Bethesda, MD: American Fisheries Society, Symposium 12, pp. 217-280.

Weithman A.S. \& Haverland P. (1991) Comparability of data collected by telephone and roving creel surveys. In: D. Guthrie, J.M. Hoenig, M. Holliday, C.M. Jones, M.J. Mills, S.A. Moberly, K.H. Pollock \& D.R. Talhelm (eds) Creel and Angler Surveys in Fisheries Management. Bethesda, MD: American Fisheries Society, Symposium 12, pp. 67-73. 